\title{
The Mind in the Old English Prose Psalms
}

\section{Abstract:}

The Prose Psalms, an Old English translation of the first fifty psalms into prose, have often been overshadowed by the other translations attributed to Alfred the Great: the Old English Pastoral Care, with its famous preface, and the intellectually daring Old English translations of Boethius's Consolation of Philosophy and Augustine's Soliloquies. However, this article proposes that, regardless of who wrote them, the Prose Psalms should be read alongside the Old English Consolation and the Soliloquies: like the two more well-studied translations, the Prose Psalms are concerned with the mind and its search for true understanding. This psychological interest is indicated by the prevalence of the word $\bmod$ ('mind') in the Old English text, which far exceeds references to the faculty of the intellect in the Romanum source. Through comparison with the Consolation and the Soliloquies, this article demonstrates that all three texts participate in a shared tradition of psychological imagery. The three translations may well, therefore, be the result of a single scholarly environment, perhaps enduring for several decades, in which multiple scholars read the same Latin, patristic writings on psychology, discussed these ideas among themselves, and thereby developed the vernacular discourse observable in these three translations. Whether this environment was identical with the scholarly circle which Alfred gathered at the West Saxon court remains a matter for debate.

The Old English prose translation of the first fifty Psalms presents a dramatic rewriting of this sacred and familiar text. ${ }^{1}$ One hitherto overlooked aspect of the Old English adaptation is the translator's concern with the workings of the mind, demonstrated by the tendency to introduce the word $\bmod$ ('mind') when there is no mention of a faculty of thought or feeling 
in the Romanum source, and the use of mod to translate the words cor ('heart') or anima ('soul'). ${ }^{2}$ The debates about the authorship of the translations traditionally attributed to Alfred invite closer scrutiny of the relationships between the texts of this corpus, regardless of one's stance on Alfred's personal involvement. ${ }^{3}$ This interest in $\bmod$ strongly suggests that the Prose Psalms should be read alongside the two other works of the Alfredian canon which explore psychology in some detail, the Consolation and Soliloquies; those two translations seem to have been carried out by one person. ${ }^{4}$ While the presentation of the mind in the Consolation and Soliloquies has received much critical attention as part of the growing scholarly interest in Anglo-Saxon psychology, the Prose Psalms have until now been largely overlooked in this context. ${ }^{5}$ Ideological and lexical correspondences between all three texts on the subject of the mind support the hypothesis that the translator of the Prose Psalms was working in the same intellectual environment as the author of the other two translations, perhaps sharing the same Latin sources, or perhaps drawing directly on the other Old English translations. While it could be argued that a single individual was responsible for all three translations, it is perhaps more realistic to imagine a scholarly environment in which multiple individuals were reading and discussing the same Latin texts on the nature of the mind, and perhaps consulting one another's translations. It is even possible to speculate that a particular psychological discourse in the vernacular could have lasted for several decades in such an environment, meaning that the individual translators need not necessarily have ever spoken directly to one another.

The Old English Consolation and Soliloquies draw upon the Christian and Platonic traditions found in their source texts, Boethius's De Consolatione Philosophiae and Augustine's Soliloquia. ${ }^{6}$ In the Old English translations, or rewritings, the mod represents one aspect of the unitary soul, that which precedes, exists in and succeeds the body. According to 
the Anglo-Latin traditions familiar to these authors, the unitary soul is made up of different elements which perform individual functions, as in Alcuin's De Ratione Animae (DRA):

Atque secundum officium operis sui variis nuncupatur nominibus: anima est, dum vivificat; dum contemplatur, spiritus est; dum sentit, sensus est; dum sapit, animus est; dum intelligit, mens est; dum discernit, ratio est; dum consentit, voluntas est; dum recordatur, memoria est. Non tamen hæc ita dividentur in substantia, sicut in nominibus; quia hæc omnia, una est anima. $^{7}$

(Also according to the function of what it does, it is called by various names: it is anima when it brings life; when it contemplates it is spiritus; when it feels it is sensus; when it knows it is animus; when it comprehends it is mens; when it discriminates it is ratio; when it consents it is voluntas; when it remembers it is memoria. Yet these things are not divided in substance, as in names; for the one soul is all these. $)^{8}$

By focussing in particular on the mod, the vernacular term for the element of the unitary soul responsible for thought, the Prose Psalms recall the psychological concerns of the Consolation and Soliloquies; in the former, the first-person speaker, Boetius or Mod, converses with Wisdom ('wisdom') and, sometimes, Gesceadwisnes ('reason'); in the latter, the dialogue is between the first-person speaker Augustinus and Gesceadwisnes. These dialogues enact the individual's quest for true happiness and complete understanding, both of which are synonymous with knowing God as He really is. The Prose Psalms, I shall argue, offer a similar account of the mod's journey to God. This translation, therefore, ought to be read as a companion to the more overtly psychological dialogues, the Consolation and Soliloquies.

The Old English Prose Psalms: Manuscript and Authorship

The only surviving copy of the Prose Psalms is found in Paris, Bibliothèque nationale de France, MS Fonds latin 8824, ff. 1-63v, the so-called 'The Paris Psalter'. ${ }^{9}$ While Patrick O'Neill suggests a date for the copying of the Paris Psalter between 1030 and $c .1050$, the translation itself can be dated before the tenth century, as it was before this point that the translator's major sources were in circulation. ${ }^{10}$ The Prose Psalms are not a word-for-word 
rendering of the Psalter in English, but rather a rewriting. While the translation is closer to its source than the Consolation or Soliloquies, it nonetheless transcends the close translation of the Anglo-Saxon Psalter-glossing tradition in its sometimes substantial adaptation of the Latin text. One of the most distinctive features of this adaptation is the fourfold scheme of interpretation offered in the introductions, which differs from the traditional allegorical fourfold scheme of historical, typological or Christological, moral and anagogical interpretations in that it offers two historical interpretations, one Christological and one moral, though in practice, many psalms have only three interpretations, featuring only one historical clause, and some only one have interpretation. ${ }^{11}$ As Emily Butler has shown, the historically-focussed introductions present Old Testament history, namely the experiences of kings David and Hezekiah and their people, as a relevant model for the contemporary AngloSaxon audience. ${ }^{12}$ This historical focus in the introductions is consonant with the translator's unusual tendency to follow the literal or historical, rather than allegorical, interpretation of the Psalms. The historical tradition of Psalter commentary was known in the West mainly through Latin translation of Theodore of Mopsuestia's Greek commentary; O’Neill argues that as the Irish 'were the main transmitters of Theodore during the early Middle Ages', it seems very likely that the translator of the Prose Psalms made use of a Hiberno-Latin commentary on the Psalms, especially as the fourfold interpretative scheme featuring two historical introductions probably originated in Ireland. ${ }^{13}$

In these introductions, the translator places a great deal of emphasis on David as original composer of the Psalms. ${ }^{14}$ This Davidic focus could be viewed as support for King Alfred's authorship of the translation, given that Asser's biography of Alfred appears to emphasize the correspondences between the two kings, perhaps as an attempt to portray Alfred as a novus David. ${ }^{15}$ However, the attribution to Alfred does not come in the Prose Psalms or in a preface, but from the historian William of Malmesbury, writing a few hundred 
years later, who states that Alfred began a translation of the Psalms. ${ }^{16} \mathrm{O}$ 'Neill, while acknowledging that William is not always a reliable source regarding Alfred's authorship, argues that the incomplete status of the translation provides support for William's claim. ${ }^{17}$ Moreover, it is possible that a preface containing an attribution to Alfred may have been removed some time after the composition of the Prose Psalms, as happened in the case of one copy of the Old English Pastoral Care. ${ }^{18}$ Support for Alfred's authorship could be found in the correspondences between the Prose Psalms and the other Alfredian translations, though the issue of whether Alfred wrote anything is still contentious. These correspondences may, in any case, indicate a shared production context, regardless of whether Alfred was involved. ${ }^{19}$ The major sources used by the translator were current prior to the tenth century, which does accord with the attribution to Alfred. ${ }^{20}$ Moreover, the translation is consonant with the aims laid out in the prose preface to the Pastoral Care both in terms of its pedagogy and its suitability as a book 'niedbeðearfosta' ('most necessary') for all men to know. ${ }^{21}$ Furthermore, as O'Neill argues, the translator's 'exegetical idiosyncrasies' seem to indicate that he or she was not a typical biblical commentator but, rather, 'an "outsider", ${ }^{22}$ Alfred would indeed be just such a figure, though it remains that the scholarship behind the Prose Psalms draws upon the relatively obscure, historically focussed branch of Psalter commentary, which would arguably have been inaccessible to a layman, king or not. However, it seems reasonable to allow for the possibility that the king's own translation of the sacred text could have been supplemented by the learning of his scholars. ${ }^{23}$ In the present discussion, the primary concern is not whether Alfred was the translator of the Prose Psalms, or any of the works attributed to him, but rather the similarities between the translations. These similarities could arguably be the result of the texts being produced in a single scholarly environment, in which the same Latin texts on the nature of the mind were in circulation. Several areas of correspondence between the Prose Psalms and the other texts 
have already been established, and it is to this pre-existing group of observations that my conclusions regarding mod can be added. ${ }^{24}$

The Prose Psalms share with not only the Consolation and Soliloquies, but also the Pastoral Care, a pragmatic, didactic style which values the plain and concrete over the ambiguous and abstract. ${ }^{25}$ Likewise, many scholars have noted shared vocabulary, phrasing and imagery among the four translations. ${ }^{26}$ One example related to the psychological concerns of the two dialogues and, I shall argue, the Prose Psalms, is the rhetorical device of pairing body and mind, seen and unseen, or the outer and inner, as in the introduction to Ps $(P)$ 12: 'his feondum, ægper ge gastlicum ge lichamlicum' ('his enemies, both spiritual and material'), which can be compared with similar phrasing in both the Consolation: 'ealle pæs monnes good, ge gastlice ge lichomlice' (B34.128, 'all the man's goods, both spiritual and material') and the Soliloquies: 'Purh pe we ofercumað ure feond, ægpær ge gastlice ge lichamlice' (51.21-2, 'through you we overcome our enemies, both spiritual and bodily'). ${ }^{27}$ Similarly, the introduction to $P s(P)$ 30: 'awðer oppe on mode oppe on lichaman' ('either in mind or body') can be compared with similar phrasing in the Soliloquies: 'awðer oððe on mode oððe on lichaman' (80.17). ${ }^{28}$ As will be demonstrated below, there are many such correspondences between these three texts in passages on psychology and the life of the mod.

\section{Mod ('Mind')}

The Prose Psalms have received little attention in criticism on psychology in Anglo-Saxon literature, a field which has recently been shaped by the work of Leslie Lockett and Britt Mize. ${ }^{29}$ This line of criticism arguably has its origins in Malcolm Godden's seminal article, 'Anglo-Saxons on the Mind' ${ }^{30}$ Godden, who makes no mention of the Prose Psalms in this piece, positions the Alfredian understanding of the mind within the Anglo-Latin and vernacular prose traditions of Alcuin and Ælfric, which are distinct from the tradition 
preserved in vernacular poetry: he emphasizes that the Alfredian corpus places very high value on the mind, and associates it with 'the soul or immortal life-spirit'. ${ }^{31}$ The Consolationauthor's interest in the mod is clearly visible in the frequent designation of the character Boetius as Mod.

Lockett has built substantially upon Godden's work. She argues that both the Consolation and the Soliloquies show awareness of the Platonist-Christian concept of the unitary soul, which is rational, incorporeal and immortal. ${ }^{32}$ The Consolation, she argues, represents a developing understanding of the unitary soul through contact with the Latin Soliloquia: as such, the translation at times preserves the vernacular distinction between mod and sawl, and at times promotes the concept of the unitary soul, drawing upon Alcuin's $D R A .^{33}$ Lockett argues that at the beginning of the Old English Soliloquies, Augustinus is presented as an 'adherent of vernacular psychology'; in other words: 'He believes that the sawl is immortal but excluded from mental activity, while the mod, the locus of mental activity and personality, cannot participate in the afterlife. ${ }^{34}$ Whereas the object of the Latin dialogue is to bring 'Augustine' to the conclusion that his unitary soul is immortal, Lockett argues that in the Old English, Augustinus accepts the soul's immortality, but must learn that the mod is part of the $s a w l$, and thus is likewise eternal. ${ }^{35}$ The author of the Soliloquies certainly draws upon the concept of the unitary soul in the Old English dialogue, whether or not Augustinus is presented as an 'adherent of vernacular psychology', as Lockett suggests.

The Prose Psalms can be seen to depend upon the same psychology as the Consolation and Soliloquies, and is likewise interested in the mod, the element of the unitary soul which engages in mental activity. Bosworth-Toller $(B-T)$ offers two senses of mod under its primary definition: 'the inner man, the spiritual as opposed to the bodily part of man' and 'soul, heart, spirit, mind, disposition, mood' ${ }^{36}$ According to this definition, then, mod can refer to many elements of the unitary soul, though Soon-Ai Low observes that mod was the 
main gloss for mens and animus, both of which correspond to Modern English 'mind' ${ }^{37}$ Mod can moreover be distinguished from heorte in that, while, for vernacular poets at least, the heorte seems to be the locus of mental activity, the mod is the agent of this activity: the distinction is one between the mind and, to borrow Lockett's term, 'the mind's bodily seat'. ${ }^{38}$ In the context of the present discussion, it is significant that the translator of the Prose Psalms so often chooses this word, given the wide range of words for 'heart', 'mind' or 'soul' in Old English, and the significant part that mod plays in the Alfredian depiction of the soul's quest for true wisdom. The translator often introduces the word $\bmod$ when there is no reference made to the intellectual faculty in the Romanum text of the Psalms, as in the translation of 'expecta Dominum' in Ps. 26.14 ('expect the lord'), which becomes 'Hopa nu, min mod, to Drihtne' $\left(P s(P) 26.15\right.$, 'have confidence, my mind, in the Lord'). ${ }^{39}$ Mod sometimes occurs as a translation for Latin words for body parts, as in ‘ne on his mode ne byð facen’ $(P s(P)$ 31.2, 'nor is there deceit in his mind'), where mod translates os ('mouth'), ${ }^{40}$ or 'pæt ponne mæge unrote mod blissian' $(P s(P) 50.9$, 'that then the sad mind may rejoice'), where mod translates ossum ('bone'). ${ }^{41}$ The mind also becomes a conduit for speech, between the Psalmist and other people in $P s(P)$ 3.1; between the Psalmist and himself in 31.6; and between God and David, as in 14.2: 'Pa answarode Drihten pæs witgan mode purh onbrydnesse pæs Halgan Gastes' ('Then the Lord answered the mind of the prophet through the inspiration of the Holy Ghost'). ${ }^{42} P s(P) 14.2$ and 45.8 are especially significant, as they imply that it is through the mod that David could communicate with God. Moreover, in Ps(P) 32.10, God's cor ('heart') becomes His mod: 'Ac Godes gepeaht wunað on ecnesse, and gepoht his modes a weorulda weoruld' ('But God's counsel dwells in eternity, and the thought of His mind for ever and ever'). ${ }^{43}$ These adaptations, taken together, perhaps reflect a belief that a channel of communication existed between David's mod and that of God. 
Elsewhere, the translator takes a spiritual struggle and locates it in a specifically mental context. The Romanum text of Ps. 23.3-4 reads: ‘(3) quis ascendit in montem Domini aut quis stabit in loco sancto eius (4) innocens manibus et mundo corde qui non accepit in uano animam suam nec iurauit in dolo proximo suo' ('[3] who ascends the mountain of the Lord or who shall stand in His sacred place? [4] The innocent of hands and clean of heart who has not taken his soul in vain nor sworn with deceit to his neighbour'). In the Old English, anima becomes mod: 'se pe ne hwyrfð his mod æfter idlum gepohtum and him mid weorcum fulgæð (peah hi him on mod cumen)' $(P s(P)$ 23.4, 'he who does not turn his mind after idle thoughts and carry them out with works [though they come into his mind]'). ${ }^{44}$ The Old English version is explicitly concerned with the mod, and how its processes relate to the body's enactment of deeds. The addition which, in O'Neill's edition, appears in parentheses stipulates that sin comes not from the presence of idle thoughts in one's mind, but in deliberately turning one's mind towards these thoughts and, crucially, allowing them to govern one's actions. A spiritual struggle has become one explicitly concerned with the relationship between thought and action.

While most Anglo-Saxon glossed psalters consistently translate cor ('heart') as heorte and anima ('soul') as sawl, as can be witnessed in the tables below, which show the glosses of the first ten occurrences of cor and anima in the Vespasian and Regius Psalters, the Prose Psalms of the Paris Psalter often feature mod instead of these expected glosses. ${ }^{45}$

\begin{tabular}{|c|c|c|c|}
\hline Table 1: Glosses for cor & Vespasian Psalter & Regius Psalter & $P s(P)$ \\
\hline Ps. 4.3 & heorte & heorte & $\begin{array}{l}\text { hardheort ('hard- } \\
\text { hearted') }\end{array}$ \\
\hline Ps. 4.5 & heorte & heorte & $\bmod$ \\
\hline Ps. 4.7 & heorte & heorte & heorte \\
\hline Ps. 5.10 & heorte & heorte & $\bmod$ \\
\hline Ps. 7.10 & heorte & heorte & $\begin{array}{l}\text { heorte and gepoht } \\
\text { ('thought') }\end{array}$ \\
\hline Ps. 7.11 & heorte & heorte & heorte \\
\hline Ps. 9.2 & heorte & heorte & heorte \\
\hline Ps. 9.27 & heorte & heorte & $\bmod$ \\
\hline
\end{tabular}




\begin{tabular}{|l|l|l|l|}
\hline Ps. 9.32 & heorte & heorte & mod \\
\hline Ps. 9.34 & heorte & heorte & mod \\
\hline
\end{tabular}

\begin{tabular}{|l|l|l|l|}
\hline $\begin{array}{l}\text { Table 2: Glosses for } \\
\text { anima }\end{array}$ & Vespasian Psalter & Regius Psalter & Ps(P) \\
\hline Ps. 3.3 & sawl & sawl & mod \\
\hline Ps. 6.4 & sawl & sawl & sawl and mod \\
\hline Ps. 6.5 & sawl & sawl & sawl \\
\hline Ps. 7.3 & sawl & sawl & sawl \\
\hline Ps. 7.6 & sawl & sawl & sawl \\
\hline Ps. 9.24 & sawl & sawl & no translation \\
\hline Ps. 10.2 & sawl & sawl & me \\
\hline Ps. 10.6 & sawl & sawl & sawl \\
\hline Ps. 12.2 & sawl & sawl & sawl \\
\hline Ps. 15.10 & sawl & sawl & sawl and mod \\
\hline
\end{tabular}

As can be seen above, the -translator of the Prose Psalms sometimes translates these words as mod or uses mod as a word-pair with the traditional translation choice. For example, the Romanum text 'ponite corda uestra in uirtute eius' (Ps. 47.14, 'set your hearts on her strength') becomes 'fæstniað eower mod on his wundrum' $(P s(P) 47.11$, 'fasten your mind on his wonders'). The following table demonstrates the extent of such transformations in the Prose Psalms:

\begin{tabular}{|c|c|c|c|c|c|c|c|}
\hline $\begin{array}{l}\text { Table 3: } \\
\text { Translations } \\
\text { of cor and } \\
\text { anima in } \\
P s(P)\end{array}$ & $\begin{array}{l}\text { Total in } \\
\text { Romanum } \\
\text { Psalter, } \\
\text { Pss. 1-50 }\end{array}$ & $\begin{array}{l}\text { Translations } \\
\text { in } P s(P)\end{array}$ & $\begin{array}{l}\text { Single } \\
\text { translations: } \\
\text { gloss expected } \\
\text { from glossed } \\
\text { psalters (cor = } \\
\text { heorte; anima = } \\
\text { sawl) }\end{array}$ & $\begin{array}{l}\text { Single } \\
\text { translations: } \\
\text { mod }\end{array}$ & $\begin{array}{l}\text { Single } \\
\text { translations: } \\
\text { something } \\
\text { else }\end{array}$ & $\begin{array}{l}\text { Word-pair } \\
\text { translations: } \\
\text { gloss } \\
\text { expected } \\
\text { from } \\
\text { glossed } \\
\text { psalters, } \\
\text { plus mod }\end{array}$ & $\begin{array}{l}\text { Word-pair } \\
\text { translations: } \\
\text { gloss expected } \\
\text { from glossed } \\
\text { psalters, plus } \\
\text { something else }\end{array}$ \\
\hline Cor & 61 & 57 & 28 & 20 & 4 & 4 & 1 \\
\hline Anima & 56 & 52 & 30 & 9 & 4 & 9 & 0 \\
\hline
\end{tabular}

When the translator glosses cor with just one word, mod is the choice over a third of the time: this is too great a rate of occurrence to be purely coincidental. The statistics for word-pairs are equally high, with all but one occasion (80\%) heorte and mod. The Psalms are inherently emotional, concerned with lament, praise and devotion. It is not surprising, then, that the first fifty Psalms contain sixty-one occurrences of the word cor: what is surprising is that the Old 
English translator of this sacred text repeatedly rejects the traditional translation choice of the glossed psalters, heorte, in favour of mod. This focus on mod recalls the Soliloquies and, to a greater extent, the Consolation, in which the first-person speaker is frequently designated $\operatorname{Mod}^{46}$

The evidence offered here constitutes the foundations upon which the more complex hypothesis of the shared psychology of the Prose Psalms, the Consolation and the Soliloquies can now be constructed. The shared presentation of psychology in these translations could be a result of Alfred's decision to gather scholars to the West Saxon court from various locations in Europe: it is easy to imagine how this group of individuals could have exchanged Latin sources, ideas and techniques for expressing these ideas in the vernacular. ${ }^{47}$

\section{The Prose Psalms and the Consolation and Soliloquies}

Table 3 shows that the translator of the Prose Psalms places far greater emphasis on the mod, the faculty of thought, than either their main source, the Romanum Psalter, or the AngloSaxon Psalter-glossing tradition. Building on these observations, I shall argue that the mod of the Prose Psalms should be understood in similar terms to the Mod of the Consolation, which is often used instead of Boetius or ic ('I') to designate the first-person speaker of the dialogue, and the first-person speaker of the Soliloquies, who, though not referred to as Mod, seems to represent Augustinus's inner thought. This is certainly the way that the dialogue is presented in the preface, which describes the text that follows as: 'hu hys [Augustinus's] gesceadwisnes answarode hys mode ponne pæt mod ymbe hwæt tweonode oðpe hit hwæs wilnode to witanne pæs pe hit ær for sweotole ongytan ne meahte' (48.15-7, 'how his reason answered his mind when that mind was doubting something or it wanted to know about something which it previously could not understand clearly'). The Prose Psalms can be read 
in the same terms as these dialogues, in which the mod is in dialogue with something greater than itself, whether its own Reason or divine Wisdom. ${ }^{48}$

The mod of the Prose Psalms experiences similar emotional states to the Mod of the Consolation. The opening account of how Wisdom comes into Boetius's mind focuses on the current sadness of Mod: 'pa com pær gan in to me heofencund wisdom and pæt min murnende mod mid his wordum gegrette' (B3.1-3, 'then divine wisdom came into me there and greeted with his words that mourning mind of mine'). The ensuing dialogue enacts Mod's journey from the sadness brought on by Boetius's preoccupation with worldly things to the happiness of the summum bonum ('highest good'). In the Prose Psalms, the ambiguous 'animam meam convertit' (Ps. 22.3, 'He has converted my soul') becomes 'and min mod gehwyrfde of unrotnesse on gefean' $(P s(P) 22.2$, 'and my mind turned from sadness to joy'). The translator's choice of words, not only the decision to translate anima as mod, but also the addition of both unrotness and gefea, recalls the description of Mod in the Consolation; moreover, mod becomes the subject in the Old English, emphasising the agency of this faculty. ${ }^{49}$ In the Consolation, Wisdom observes: 'Ic geseo pæt pe is nu frofres mare pearf ponne unrotnesse' (B3.28-9, 'I see that you now have greater need of comfort than sadness'), and Mod is termed 'pæt unrote mod' (B3.31-2, 'that sad mind', emphasis added). ${ }^{50}$ Moreover, Wisdom laments that the mind suffers when it forgets 'his ahgen leoht, pæt is ece gefea' (B3.24, 'its own light, that is, eternal joy', emphasis added), and pushes forward instead in the darkness of 'woruldsorga, swa swa ðis mod nu deð' (B3.25, 'worldly sorrows, just as this mind now does'). $P s(P) 22.2$ can be read in similar terms, as the mind's turning away from the sorrows of this world, into the joy of its 'ahgen leoht' ${ }^{51}$

Like the Consolation and Soliloquies, the Prose Psalms capture the mind's pursuit of this light of complete happiness and knowledge. Despite the different genres of psalm and philosophical dialogue, the Prose Psalms are nonetheless suffused with the same 
psychological preoccupations of the Consolation and Soliloquies. In the dialogues, dysig ('foolishness') represents one of the barriers which the mod must overcome if it wants to reach its goal. ${ }^{52}$ An adaptation made by the translator of the Prose Psalms suggests that they too saw dysig as something that needs to be repudiated. Ps. 39.5 warns against vanity and folly: 'beatus uir cuius est nomen Domini spes eius et non respexit in uanitatem et in insanias falsas' ('blessed is the man whose trust is in the Lord's name and who does not care for vanities and lying follies'). The Old English translation follows the Latin fairly closely: 'Eadig byð se wer pe his tohopa byð to swylcum Drihtne and ne locað næfre to idelnesse ne to leasungum ne to dysige' $(P s(P) 39.4$, 'Blessed is the man whose hope is to such a Lord and never looks to idleness nor to lying nor to foolishness'). While dysig approximates the sense of insanias in Ps. 39.5, its appearance here distinguishes the usage of the Prose Psalmstranslator from that of Anglo-Saxon glossed psalters: the glosses listed by Philip Pulsiano include, among others, wedenheortness ('madness, frenzy, fury'), gewitleast ('folly, madness, phrensy') and wodness ('madness, fury, frenzy, rage'), a strikingly varied range of terms for a corpus with a typically homogenous vocabulary. ${ }^{53}$ The choice of the Prose Psalms here reflects the usage of the Consolation and Soliloquies, where dysig represents the barrier which prevents the mind from fulfilling its potential. For example, in the Consolation, Wisdom laments: 'Walawa, hu hefig and hu frecendlic pæt dysig is pe ða earman men gedwelað and alæt of pam rihtan weg. Se weg is God' (B32.67-9, 'Alas, how grievous and how dangerous that folly is which deceives wretched men and leads them from the right way. The way is God'). ${ }^{54}$ Likewise, in the Soliloquies, Augustinus prays: 'gehæl mine eahgan and untyn, pæt ic mage geseon pine wundru; and adrif fram me dysig and ofermæto, and sile me wisdom, pæt ic mage pe ongytan' (54.18-20, 'heal and open my eyes, so that I may see your wonders; and drive out from me foolishness and pride, and give me wisdom, that I may perceive you'). ${ }^{55}$ In these examples, dysig represents an impediment to knowing God. Read in 
this light, the dysig of $P s(P) 39.4$ takes on a new meaning and lends greater significance to this deviation from the standard choice of gloss in Anglo-Saxon psalters: the translation choice recalls the usage of the Consolation and Soliloquies, in which dysig must be eliminated before the soul can begin to know God.

The imagery of seeing clearly, as in the quotation above, pervades both dialogues and is integral to the depiction of the mind's quest for true understanding. In both the Consolation and the Soliloquies the eage modes ('mind's eye') represents the faculty with which one 'sees' God, and which is lit not with the light of the sun but that of wisdom. ${ }^{56}$ In the Consolation, Wisdom prays:

Forgif nu drihten urum modum pæt hi moton to pe astigan purh pas earfoðu pisse worulde, and of pissum bisegum to pe cuman, and openum eagum ures modes we moten geseon pone æpelan æwelm ealra goda, pæt eart ðu. Forgif us ponne hale eagan ures modes pæt we hi ponne moton afæstnian on pe and todrif ðone mist pe nu hangað before ures modes eagum and onliht pa eagan mid ðinum leohte (B33.241-7). ${ }^{57}$

(Lord, give to our minds that they may climb to you through the hardships of this world, and come to you through these troubles, and with the eyes of our mind open we might be permitted to see the noble wellspring of all good, which is you. Give us then healthy mind's eyes so that we may then fasten on you and drive away the mist which now hangs before our mind's eyes and enlighten those eyes with your light).

The preoccupations of this world are figured as mist which clouds the mind's eye, preventing it from seeing clearly. While the parallel passage in Boethius's Latin metre also features the image of the mind's sight, it is the Old English author who introduces the phrase eagan modes ('eyes of the mind'), and moreover repeats the same phrase on two further occasions in the translation of this section of the metre. As Miranda Wilcox has shown, the Old English author not only modifies the visual metaphors present in the Latin text, but moreover adds many of their own; on several occasions, these metaphors employ the phrase eagan modes, despite the fact that the genitive phrase 'oculi mentis' ('eyes of the mind') does not occur at all in De Consolatione. ${ }^{58}$ It is worth noting the prevalence of the modal motan ('may') in this 
passage, especially the subjunctive form in 'moten geseon' ('might be permitted to see'): there is little assurance that this clear sight is attainable, at least in this life.

In the Soliloquies, Augustinus asks 'hwæt is pæt ðæt pu hest modes eagan?' and receives the answer 'gesceadwisnes, to-æacan oðrum creftum' (62.4-5, 'what is that that you call the mind's eye?'; 'reason, in addition to other virtues'). To 'see clearly', then, with the eagan modes is a rational act. Like Wisdom, Gesceadwisnes emphasizes the importance of healthy eyes: 'Ac se pe god geseon wille, he scel habban his modes eagan hale: pæt is, ðæt he hebbe festne geleafan and rihte tohopan and fulle lufe' (67.3-5, 'But he who wishes to see God, he must have healthy mind's eyes: that is, that he has firm faith, right hope and full love'). However healthy one's eyes are, in the Soliloquies, the full knowledge that the mind strives for is denied during the mortal life of the body:

Ac pæt mod is mid pa lichaman gehefegod and abysgod, pæt we ne magon myd pæs modes eagum nan ping geseon swylc swilc hyt is, ðe ma pe ðu myht hwilum pære sunnan scyman geseon ponne pa wolcnan sceotað betweon hyre and pe; and peah heo scyneð swiðe beorhte pær per heo bið. ne furðum peah per nan wolcne si betweon pe and hyre, pu hy ne myht ful sweotole geseon swilce swilc heo is, forðam pu ne eart ðer heo is. ${ }^{59}(92.22-93.6)$

(But that mind is burdened and preoccupied by the body, so that we may not see anything just as it is with the mind's eyes, any more than you could see for a time the sun's shining when the clouds shoot between it and you; and even if it shines very brightly there where it is, nor even if there were no clouds between you and it, you could not see it full clearly as it is, because you are not where it is.)

But, as Gesceadwisnes goes on to say, when the soul leaves the prison of the body then, 'butan ælcum tweon' (93.14, 'without any doubt'), it will know all it wishes to know. ${ }^{60}$ Wilcox notes the many occurrences of the phrase eagan modes in the Soliloquies, none of which correspond to the phrase oculi mentis in the source, though Augustine does use the image of sight to represent mental activity. ${ }^{61}$

The phrase eagan modes appears on three occasions in the Prose Psalms, as in $P s(P)$ 13.8: 'ne Godes ege ne byð beforan heora modes eagum' ('nor is God's terror before the eyes of their mind') and 16.10 'pa eagan heora modes habbað geteohhod pæt hi me gebygen oð 
eorðan' ('the eyes of their mind have determined that they bow me down to the earth'). ${ }^{62}$ The third appearance occurs in $P s(P)$ 18.8, translating Ps. 18.9: 'praeceptum Domini lucidum inlumians oculos' ('The Lord's commandment is shining, enlightening the eyes'). In the Old English this becomes: 'Godes bebod is swiðe leoht: hit onliht pa eagan ægper ge modes ge lichaman' ('God's command is very light: it enlightens both the eyes of the mind and the body'). In this verse, the translator of the Prose Psalms again refers to the contrasting states of mind and body which, as discussed above, is a device also found in the Consolation and Soliloquies. ${ }^{63}$ Traditional allegorical commentaries on the Psalms also make the contrast between literal and metaphorical eyes in relation to this verse. However, both Augustine and Cassiodorus emphasise that the eyes to which the Psalmist refers in Ps. 18.9 are not of the body: for Augustine they are the eyes of the heart, and for Cassiodorus, those of man's interior being. ${ }^{64}$ If the translator did make use of these allegorical commentaries, he or she directly contradicts their interpretation of this verse, introducing a formulaic phrase familiar from the vernacular Consolation and Soliloquies, 'ægper ge modes ge lichaman' ('both of mind and of body'), which expresses precisely the opposite meaning.

The image of the mind's eye being illuminated by the light of God in $P s(P) 18.8$ recalls the imagery of both the Consolation and Soliloquies. Both Boethius and Augustine employ the well-known metaphor by which sight represents cognition, and by which, therefore, clear and unimpeded sight represents the complete knowledge of God. ${ }^{65}$ It is certainly possible, therefore, that the translator of the Prose Psalms did not have access to the Old English translations of these texts, but rather knew only the Latin versions. However, it is striking that the translator employs not only this imagery, but the specific metaphor of the eagan modes which appears in the quotation from the Consolation above, to give just one example from that text: 'todrif ðone mist pe nu hangað beforan ures modes eagum and onliht pa eagan mid ðinum leohte' (B33.245-7, 'drive away the mist which now hangs before our 
mind's eyes and enlighten those eyes with your light'). Similarly, the eagan modes metaphor occurs frequently in the Soliloquies; for example: 'swa swa peos gesewe sunne ures lichaman æagan onleoht, swa onliht se wisdom ures modes æagan, pæt is, ure angyt' (78.3-5, 'just as the visible sun illuminates our body's eyes, so wisdom enlightens the eyes of our mind, that is, our understanding') ${ }^{66}$ There are numerous linguistic parallels between the three passages: the noun leoht ('light'), verb onlihtan ('enlighten') and reference to the body's and the mind's eyes. Given the parallels not only in imagery but in phrasing, it seems likely that, even if the translator of the Prose Psalms was unfamiliar with the Old English Consolation and Soliloquies, he or she may well have been working in the same environment as the author of these texts, generating or participating in this vernacular discourse about sight and cognition. The recurrence of eagan modes is perhaps the most persuasive piece of evidence for this hypothesis as, while the Latin parallel oculi mentis is very common in classical antiquity and patristic writings, all three translations feature the Old English version at points where there is no such parallel in their source texts; moreover, as Wilcox observes, the 'specific genitively linked metaphor eagan modes occurs independent of the Latin calque oculi mentis' only in the Old English Pastoral Care, Consolation, Soliloquies and Prose Psalms. ${ }^{67}$ Wilcox goes as far as to use the occurrence of this metaphor as evidence for a single, guiding will behind the Pastoral Care, Consolation and Soliloquies: while common authorship of the four translations, let alone Alfred's authorship, remains in doubt, the evidence of eagan modes certainly suggests that the creators of all four translations were working in the same environment. ${ }^{68}$ While Wilcox's study does not treat the Prose Psalms in great detail, the use of eagan modes in this translation strongly suggests that it should be read in the same light as the others. ${ }^{69}$

Elsewhere in the Prose Psalms the imagery of sight occurs in a psychological context which recalls the mind's struggles for true perception in the Old English Consolation and 
Soliloquies. In Ps. 37.11, 'cor meum conturbatum est in me et deseruit me fortitudo mea et lumen oculorum meorum non est mecum' ('my heart is disturbed within me and my strength has forsaken me and the light of my eyes is not with me'), becomes in $\operatorname{Ps}(P)$ 37.9:

Min heorte is gedrefed and min mod oninnan me, for pæm min mægen and min strengo and min cræft me hæfð forlæten, and pæt leoht and seo scearpnes minra eagena, pe ic ær hæfde, nis nu mid me swa swa ic hy geo hæfde.

(My heart is disturbed within me, and my mind, because my might and my strength and my power have abandoned me, and the light and the sharpness of my eyes, which I previously had, are now not with me as I had them before).

There are multiple adaptations in this verse. Firstly, cor is translated by the word-pair heorte and mod: while, for the translator, heorte may have indicated the bodily seat of thought, it is $\bmod$, the mind, which engages actively in mental activity. ${ }^{70}$ Moreover, in the Consolation it is the mod, rather than the heorte, which interacts with wisdom and reason. This adaptation suggests, then, that the translator was at pains to express the disturbance caused to the speaker's mental faculties. Secondly, the word craft is an unnecessary addition, as the sense of fortitudo has already been amply conveyed by magen and strengu: the latter are the translations offered in the glossed psalters. ${ }^{71}$ Yet craft ('power, skill, virtue') is an integral word in the Alfredian corpus: the authors of these texts employ it innovatively, using the word to form a connection between physical, mental and moral abilities. ${ }^{72}$ In the Alfredian context, the word craft forms a bridge between secular 'skill' and religious virtue. As such, pursuing even worldly wisdom can be a part of the moral life. The connection between mental and moral abilities corresponds to the close association between intellectual and spiritual enlightenment in the Consolation and the Soliloquies. Thirdly, the translator of the Prose Psalms not only renders 'lumen' as 'pæt leoht', but moreover adds 'seo scearpnes' ('the sharpness'): while scearp and eage is not an uncommon collocation in the Old English corpus, there are instances in both the Old English Consolation and Soliloquies in which they 
occur together in relation to the sharpness of the mind's eye. In the Consolation, Wisdom sings:

Ac pa gyldenan stanas and pa seolfrenan and ælces cynnes gimmas and eall pes andwearda wela ne onlihtað hi nauht pæs modes eagan, ne heora scearpnesse nauht gebetað to pære sceawunga pære soðan gesælðe. ${ }^{73}$ (B34.196-9)

(But those golden and silver stones and all kinds of gems and all this present wealth do not enlighten the mind's eyes at all, nor improve their sharpness for the contemplation of the true felicities.)

While the corresponding section in Boethius's Latin metre does refer to metaphorical sight, it is the Old English author who introduces the genitive phrase eagan modes, explicitly stipulating that the faculty of sight belongs to the mind. The scearpness in the Old English, like the acies of the Latin, evidently indicates the sharpness of intellect or reason, rather than actual sight. Likewise, in the Soliloquies, Gesceadwisnes explains to Augustinus that it is not possible for him to see wisdom 'bærne' (76.27, 'bare') in this life, but entreats him not to despair:

Đi ne sceal nan man geortriwian peah he næbbe swa hale eagan swa se pe scerpest locian mæg, ponne se ðe ealra scearpost locian mæg ne mæg peah pa sunnan selfe geseon swilce swilce heo ys, ða hwile ðe he on pis andweardan lyfe byð. (76.30-77.2)

(Therefore no man must despair even if he does not have as healthy eyes as he who can look the sharpest, when he who can look the sharpest of all cannot nevertheless see the sun itself just as it really is, while he is in this present life.)

The sharpness of eye that has departed the Psalmist in $P s(P) 37.9$ should arguably read in the context of these passages in the Consolation and Soliloquies, in which sharp eyes represent a perceptive intellect. Finally, it is worth noting the adaptations that the translator makes to 'non est mecum' ('is not with me'), which becomes 'nis nu mid me swa swa ic hy geo hæfde' ('is [are] now not with me as I previously had them'). The notion of having departed from a previous state of knowledge and happiness, to which one strives to return, can also be found 
in the Consolation and Soliloquies. It is to this theme, observable in all three Old English translations, which I shall turn by way of conclusion.

\section{Conclusion: Seeking within the Self}

The Old English Consolation, Soliloquies and Prose Psalms share a discourse in which to see clearly with the eagan modes is to attain certain knowledge: it remains to consider how this clear sight should be interpreted. Is it prayer or meditation, spoken petition or silent contemplation, achieved among companions or in isolation? A verse from the Prose Psalms can offer some indication of how the process of seeking sure knowledge was envisaged; ironically, the image involves not the sense of sight but that of hearing. ${ }^{74}$ The first part of Ps. 48.5, 'inclinabo ad similitudinem aurem meam' ('I will incline my ear to a parable'), is rendered 'Ic onhylde min earan to pam bispellum pæs ðe me innan lærð' (48.4, 'I incline my ears to the parables of that which teaches me from within'). This adaptation is strongly reminiscent of both the Consolation and the Soliloquies. In the Consolation, Wisdom enters Mod and teaches from within (B3.1-2), and in the Soliloquies, Augustinus does not know if his interlocutor is within him or without, but knows that it is his reason (49.4-6). ${ }^{75}$ Moreover, both Wisdom and Gesceadwisnes teach their students through the device of the bispell ('parable'): as Wisdom says to Mod towards the very end of the dialogue: 'Ic pe wille læran bispellum, swa ic pe eallne weg dide' (B40.87-8, 'I will teach you with examples, as I did for you the whole way'). ${ }^{76}$

Furthermore, there are instances of the mind seeking within itself in both the Consolation and Soliloquies, perhaps most notably in the Old English translation of Boethius's $3 \mathrm{~m} 11$, which is inspired by the Platonic theory of reminiscence. In this case, the Old English version follows the Latin quite faithfully: ${ }^{77}$ 
Swa hwa swa wille dioplice spirigan mid inneweardan mode æfter ryhte, and nylle pæt hine ænig mon oððe ænig ping mage amerran, onginne ponne secan oninnan him selfum pæt he ær ymbutan hine sohte, and forlæte unnytte ymbhogan swa he swiðost mæge, and gegæderige to pam anum, and gesecge ponne his agnum mode pæt hit mæg findan oninnan him selfum ealle pa god pe hit ute secð. ${ }^{78}$ (B35.2-8)

(Whoever wishes to seek thoroughly after what is right with inward mind, and does not wish that any man or anything may hinder him, let him then begin to seek within himself for that which he previously sought without him, and abandon useless cares as much as he can, and gather to the one ${ }^{79}$ and say then to his own mind that it may find within itself all those goods which it seeks without.)

The unhindered search for knowledge takes place in the 'inward mind', the place, perhaps, in which the speaker of $P s(P) 48.4$ can hear the teachings within him. The Old English author unpicks the imagery of the metre's third line, translating 'In se revolvat intimi lucem visus' with 'onginne ponne secan oninnan him selfum pæt he ær ymbutan hine sohte, and forlæte unnytte ymbhogan swa he swiðost mæge', revealing without any doubt that the subject of Wisdom's song is the search within the inner self, a clarification which Boethius does not make until lines 5-6: the result is that in the Old English version, this search within the self receives greater emphasis. Moreover, the Old English author transforms Boethius's abstract metaphor into practical instruction, applicable to real life: the searcher of truth must abandon, as much as possible, useless cares. This addition, both in its practical tone and the injunction to follow the text's advice to the best of one's ability, is characteristic of the corpus associated with Alfred. ${ }^{80}$ The object of the search is the Platonic 'corn pære soðfæstnesse sædes' (B35.17, 'grain of the seed of truth') that remains from the time when the soul preexisted the body. It is in this context that the additional words of $\operatorname{Ps}(P) 37.9$, that the speaker no longer has light and sharpness of eye 'swa swa ic hy geo hæfde' ('as I previously had them'), are particularly relevant: the Old English version of the verse implies that the speaker was previously able to see clearly, but has since lost that ability. Moreover, as Lockett demonstrates, the Soliloquies draws upon this Platonic theory of reminiscence, which is absent from the Latin Soliloquia, though she acknowledges that the Old English offers a 
'watered-down version'. ${ }^{81}$ Most strikingly for the present context, the faculty which participates in this process of recollection in the Soliloquies is the $\bmod$ rather than the $s a w l .{ }^{82}$ In these translations, the mod is that part of the unitary soul which could seek within the self for deeply buried wisdom. ${ }^{83}$ In this light, the increased reference to the mod in the Prose Psalms takes on new and striking relevance.

The search for knowledge in the Consolation, Soliloquies and Prose Psalms can therefore be read as a Christian-Platonic return to the truth and to God: the mind's eye strives through clouds of uncertainty to perceive the light of divine wisdom, which it perhaps remembers from a time before its earthly incarnation. While the Prose Psalms are not handled with as much freedom as the two philosophical dialogues, and do not offer a sustained argument concerning psychology, this Old English adaptation of the Psalter is far more concerned with the life of the mind than its biblical source. It is certainly possible that the translator of the Prose Psalms absorbed some of the imagery with which he or she depicts mental activity from patristic or classical sources: the concept of seeking within oneself for truth is not an invention of the Old English author of the Consolation and, indeed, seems to form the very basis of the dialogue between 'Augustine' and Ratio in Soliloquia; moreover, as Wilcox points out, the oculi mentis metaphor was 'commonplace' in classical philosophy. ${ }^{84}$ However, while the issue of common authorship remains unresolved, parallels in not only imagery but, significantly, phrasing suggest that the psychological discourse which is introduced in the Old English translations of both De Consolatione and Soliloquia also had a bearing upon the way in which this translator adapted the first fifty Psalms for an Anglo-Saxon audience. 
${ }^{1}$ See M. J. Toswell, The Anglo-Saxon Psalter, Medieval Church Studies 10 (Turnhout, 2014), 3-4, on the widespread familiarity of the Psalter in Anglo-Saxon England, in both lay and monastic spheres.

${ }^{2}$ The Romanum Psalter, the main source for the Prose Psalms, is the version of the Psalter which was in use in England from perhaps as early as the sixth century, when it was possibly brought over by Augustine of Canterbury from Rome, until the monastic reforms of the mid-tenth century, when the Gallicanum version became more popular (Patrick P. O'Neill [ed.], King Alfred's Old English Prose Translation of the First Fifty Psalms, Medieval Academy Books 104 [Cambridge, MA, 2001], 31). Neither mens nor animus (both 'mind') appear in the first fifty psalms.

${ }^{3}$ M. R. Godden, 'Did Alfred Write Anything?' Medium AEvum 76 (2007), 1-23; on the Prose Psalms, see 4; see also his ‘Alfredian Prose: Myth and Reality', Filologia Germanica 5 (2013), 131-58. See further Janet Bately’s response to Godden's argument, 'Did Alfred Actually Translate Anything? The Integrity of the Alfredian Canon Revisited', Medium AEvum 78 (2009), 189-215.

${ }^{4}$ Based on the many correspondences between the Consolation and the Soliloquies, Malcolm Godden and Susan Irvine argue: 'It is impossible to resist the conclusion that the two works are by the same author' (Malcolm Godden and Susan Irvine, with Mark Griffith and Rohini Jayatilaka [eds and trs], The Old English Boethius: An Edition of the Old English Versions of Boethius's De Consolatione Philosophiae, 2 vols [Oxford, 2009], 1. 1378).

${ }^{5}$ On Anglo-Saxon psychology, see M. R. Godden, 'Anglo-Saxons on the Mind', in Michael Lapidge and Helmut Gneuss (eds), Learning and Literature in Anglo-Saxon England: Studies Presented to Peter Clemoes on the Occasion of his Sixty-Fifth Birthday (Cambridge, 1985), 271-98; Leslie Lockett, Anglo-Saxon Psychologies in the Vernacular and Latin Traditions (Toronto, 2011); Britt Mize, Traditional Subjectivities: The Old English Poetics of Mentality (Toronto, 2013); Soon-Ai Low, “Approaches to the Old English Vocabulary for "Mind”", Studia Neophilologica 73 (2001), 11-22; her 'Pride, Courage and Anger: The Polysemousness of Old English Mod', in Antonina Harbus and Russell Poole (eds), Verbal Encounters: Anglo-Saxon and Old Norse Studies for Roberta Frank, Toronto Old English Series 13 (Toronto, 2005), 77-88; Antonina Harbus, The Life of the Mind in Old English Poetry, Costerus new ser. 143 (Amsterdam, 2002); and her Cognitive Approaches to Old English Poetry, Anglo-Saxon Studies 18 (Cambridge, 2012). On psychology in the Consolation and Soliloquies, see Godden, 'Anglo-Saxons on the Mind', especially 274-7; and Lockett, Anglo-Saxon Psychologies, 313-73.

${ }^{6}$ On Augustine's conflation of the Christian and Neoplatonic traditions in his Soliloquia, an early work, see R. A. Markus, ‘Augustine. Reason and Illumination', in A. H. Armstrong (ed.), The Cambridge History of Later 
Greek and Early Medieval Philosophy (Cambridge, 1970 [repr.]) 362-73 (364); and Soliloquia 1.VII.14. On

Augustine's understanding of Plato's intelligible and sensible worlds, see his Contra Academicos, III.17.37. On Augustine's conversion to 'the world of spirit', which embraces both Christianity and Neoplatonism, see St. Augustine of Hippo, Soliloquies and Immortality of the Soul, ed. and tr. Gerard Watson, Classical Texts 09537961 (Warminster, 1990), 10-1. Augustine later regretted that he made this conflation: see his Retractiones 1.4.3, on Soliloquia 1.VII.14. On Christianity in Boethius's De Consolatione, a work heavily influenced by Plato and Neoplatonism, see John Marenbon, Boethius, Great Medieval Thinkers (Oxford, 2003), 154-9.

${ }^{7}$ DRA 11 (PL 101.644). Lockett, Anglo-Saxon Psychologies, 286, n. 15, notes that Alcuin here adapts Isidore's catalogue of names, combining Differentiae 2.27 with Etymologiarum 11.1.12-3 ).

${ }^{8}$ All translations, from Latin and Old English, are original unless otherwise specified.

${ }^{9}$ This version is nearly complete: the Paris Psalter is missing a folio between ff. $20-1$ containing the end of Ps. 20 and the introduction and rubric to Ps. 21; a folio between ff. 26-7 containing the end of Ps. 25 and the introduction to Ps. 26; a folio between ff. 45-6 containing the rubric to Ps. 38 and Ps. 38.2-6a; and two folios after f. 63 containing the end of Ps. 50 (O'Neill [ed.], Prose Translation, 122, 128-9, 147, 163). Fragments of the introductions which accompany most of the Prose Psalms are also found in London, British Library, MS Cotton Vitellius E.xviii, edited in Phillip Pulsiano, 'The Old English Introductions in the Vitellius Psalter', Studia Neophilologica 63 (1991), 13-35 . As Allen J. Frantzen notes, the London manuscript does not appear to have been made from the Paris manuscript but, rather, both manuscripts seem to share a common ancestor (King Alfred, TEAS 425 [Boston, 1986], 90; see also Pulsiano, 'Old English Introductions', 13). The Paris Psalter also contains versifications of the subsequent psalms, 51-150, as well as a full Romanum version of the Psalter, with the Old English and Latin texts presented in parallel columns; as O'Neill (ed.), Prose Translation, 10, observes, the Latin of the Paris Psalter is 'not directly related' to either Old English text; see also Robert L. Ramsay, 'The Latin Text of the Paris Psalter: A Collation and Some Conclusions', The American Journal of Philology 41 (1920), 147-76 (152).

${ }^{10} \mathrm{O}$ 'Neill (ed.), Prose Translation, 21 and 74; i.e. the version of the Romanum on which the translation is based, and the putative Hiberno-Latin commentary which seems to have supplied the historical and literal interpretation so characteristic of the Prose Psalms: for more on these sources, see below.

${ }^{11}$ O'Neill (ed.), Prose Translation, 23-6; on the sources for these introductions, see 25-6.

${ }^{12}$ Emily Butler, ““And Thus Did Hezekiah”: Perspectives on Judaism in the Old English Prose Psalms', RES 67 (2016), 617-35 (see especially 617-20, 623-4, 630-5). 
${ }^{13}$ O’Neill (ed.), Prose Translation, 34 and 37-41.

${ }^{14}$ See David Pratt, The Political Thought of Alfred the Great, Cambridge Studies in Medieval Life and Thought, $4^{\text {th }}$ ser. 67 (Cambridge, 2007), 250-1, for the observation that David is presented as the author of every psalm, despite the fact that biblical tituli attribute Pss. 41, 44 and 49 to the sons of Chore and Asaph.

${ }^{15}$ See Toswell, Anglo-Saxon Psalter, 64-72, for evidence of what she sees as a determined effort on Asser's behalf to make the parallel, though it should be noted that it is Solomon, rather than David, with whom Asser directly compares Alfred (Vita Alfredi c. 76). On the parallels between Alfred and David, see further Pratt, Political Thought, 251-3; Richard Abels, Alfred the Great: War, Kingship and Culture in Anglo-Saxon England (London, 1998), 239; Daniel Orton, 'Royal Piety and Davidic Imitation: Cultivating Political Capital in the Alfredian Psalms', Neophilologus 99 (2015), 477-92 (482-3); and Butler, ““And Thus Did Hezekiah”, 626-8. ${ }^{16}$ O’Neill (ed.), Prose Translation, 73.

${ }^{17}$ O’Neill (ed.), Prose Translation, 73.

${ }^{18}$ Orton, 'Royal Piety', 479, n. 6; the manuscript is Cambridge, Trinity College, MS R. 5.22 (717), dating to the late tenth or early eleventh century.

${ }^{19}$ O'Neill (ed.), Prose Translation, 74-95 . On the uncertainty of Alfred's authorship, see Godden, 'Did Alfred Write Anything?'; on the Prose Psalms, see 4.

${ }^{20}$ O'Neill (ed.), Prose Translation, 74: the version of the Romanum Psalter on which the translation is based 'is textually akin to the early family (pre-800) of English psalters', and the putative Hiberno-Latin commentary which the translator seems to have used was superseded by the Carolingian type in the ninth century, after which it would have been increasingly unlikely to find the Hiberno-Latin kind in use outside of Ireland.

${ }^{21}$ Henry Sweet (ed. and tr.), King Alfred's West-Saxon Version of Gregory's Pastoral Care, Parts 1 and 2, EETS 45 and 50, o.s. (London, 1871-1872), 7, 11. 6-7 (all quotations from the Pastoral Care are from this edition); O’Neill (ed.), Prose Translation, 95. Moreover, David Pratt suggests that the Prose Psalms had a key role in the educational programme due to the 'sapiential character of the Psalms' (Political Thought, 261); see further Janet Bately, The Literary Prose of Alfred's Reign: Translation or Transformation? (London, 1980), 11. Daniel Anlezark, 'Which Books are "Most Necessary" to Know? The Old English Pastoral Care and King Alfred's Educational Reform', English Studies 98 (2017), $759-80$ (764-7 and 777), has recently argued that the prose preface is a demand for the translation of Scripture into English, as implied by the account of scriptural translation over time, and suggests that the Prose Psalms could be 'evidence of this abortive project'; see also Daniel Anlezark, Alfred the Great (Kalamazoo, MI, 2017), 83-5. 
${ }^{22}$ Patrick P. O’Neill, 'The Prose Translation of Psalms 1-50’, in Nicole G. Discenza and Paul E. Szarmach (eds), A Companion to Alfred the Great, Brill's Companions to the Christian Tradition 58 (Leiden, 2015) 256$81(281)$.

${ }^{23}$ Frantzen, King Alfred, 96.

${ }^{24}$ J. I'A Bromwich, 'Who Was the Translator of the Prose Parts of the Paris Psalter?', in Cyril Fox and Bruce Dickins (eds), The Early Cultures of North-West Europe (Cambridge, 1950), 289-303 (297-300); O’Neill (ed.), Prose Translation, 84-94; Janet M. Bately, 'Alfred as Author and Translator', in Discenza and Szarmach (eds), A Companion to Alfred the Great, 113-42 (125-34); Janet M. Bately, 'Lexical Evidence for the Authorship of the Prose Psalms in the Paris Psalter', ASE 10 (1981), 69-95 (82-4); and Bately, Literary Prose, 4. On the comparison of the ten psalm quotations common to both the Prose Psalms and the Pastoral Care, see O’Neill (ed.), Prose Translation, 79-83; and Frantzen, King Alfred, 102. On the biblical quotations in the Pastoral Care, see further Amy Faulkner, 'Royal Authority in the Biblical Quotations of the Old English Pastoral Care', Neophilologus 102 (2018), 125-40. For Bately's response to some dissimilarities between the vocabulary of the Prose Psalms and the other translations, see Bately, 'Lexical Evidence', 78-86.

${ }^{25}$ O’Neill (ed.), Prose Translation, 74; see further, 75-8. See also Stanley B. Greenfield and Daniel G. Calder, A New Critical History of Old English Literature (New York; London, 1986), 55.

${ }^{26}$ See above.

${ }^{27}$ Pratt, Political Thought, 256-7; and Bromwich, 'Who Was the Translator', 299. The abbreviation Ps(P) follows O’Neill (ed.), Prose Translation. All quotations from the Prose Psalms are from this edition; parenthetical references indicate psalm and Old English verse number. All quotations from the Consolation are taken from Godden and Irvine (eds and trs), Old English Boethius, 1; parenthetical references indicate the version of the text, chapter number and line number(s), with ' $\mathrm{B}$ ' referring to the B-text (Oxford, Bodleian Library, MS Bodley 180), CP to a prose section from the C-text (London, British Library, MS Cotton Otho A. vi) and CM to a metrical section from the C-text. All quotations from the Soliloquies are taken from Thomas A. Carnicelli (ed.), King Alfred's Version of St. Augustine's Soliloquies (Cambridge, MA, 1969); parenthetical references indicate page and line number(s). Editorial emendations and markers from all editions have been silently incorporated throughout.

${ }^{28}$ Bromwich, 'Who Was the Translator', 300. See also $P s(P) 18.8$ and Soliloquies 71.23-4 (Bromwich, 'Who Was the Translator', 300); for further examples of this rhetorical device in the Prose Psalms, see $P s(P) 15.7$ and the introductions to $P s(P) 3,15,10,27$ and 41. 
${ }^{29}$ Lockett, Anglo-Saxon Psychologies and Mize, Traditional Subjectivities. See Lockett, Anglo-Saxon

Psychologies, 92, for a brief remark on the imagery of burning in the depiction of anger in $P s(P) 2.13$.

${ }^{30}$ See above.

${ }^{31}$ Godden, 'Anglo-Saxons on the Mind', 275-6; Godden's comments mainly refer to the Consolation and the Soliloquies.

${ }^{32}$ On the Platonist-Christian opinions on the soul, see Lockett, Anglo-Saxon Psychologies, 182-3.

${ }^{33}$ Lockett, Anglo-Saxon Psychologies, 315-25.

${ }^{34}$ Lockett, Anglo-Saxon Psychologies, 337.

${ }^{35}$ Lockett, Anglo-Saxon Psychologies, 335-7. On Gesceadwisnes's introduction of the unitary soul, see 345-7.

${ }^{36}$ Bosworth-Toller, s.v. mod, definition I (Joseph Bosworth and T. Northcote Toller, An Anglo-Saxon Dictionary

[Oxford, 1898], henceforth referred to as $B-T$ ).

${ }^{37}$ Low, 'Pride, Courage and Anger', 77.

${ }^{38}$ Lockett, Anglo-Saxon Psychologies, 61-3.

${ }^{39}$ The Romanum features cor later in this verse, which is translated as heorte in the Old English.

${ }^{40}$ Cf. Ps. 31.2 'nec est in ore eius dolus' ('in whose mouth there is no guile'). The Gallicanum reads 'spiritu' ('spirit') in the place of 'ore'; the translator may be following the Gallicanum here, as he or she seems to when the Romanum is obscure (O'Neill [ed.], Prose Translation, 33), though it is significant nonetheless that they choose mod rather than either тиð ('mouth') or gast ('spirit'), which are used at this point in Old English glossed psalters (see Phillip Pulsiano [ed.], Old English Glossed Psalters, 1-50, Toronto Old English Series 11 [Toronto; London, 2001], 405). All quotations from the Romanum are taken from Robert Weber (ed.), Le Psautier Romain et les Autres Anciens Psautiers Latins: Édition Critique, Collectanea Biblica Latina Cura et Studio Monachorum S. Benedicti 10 (Rome, 1953). All quotations from the Gallicanum are from Robert Weber et al. (eds), Biblia Sacra Iuxta Vulgatam Versionem, $5^{\text {th }}$ edn (Stuttgart, 2007).

${ }^{41}$ Cf. Ps. 50.10 'et exultabant ossa humiliata' ('and bones that have been humbled shall rejoice').

${ }^{42}$ See also $P S(P)$ 45.8. Cf. Pss. 3.3, 31.5, 14.2 and 45.10.

${ }^{43}$ Cf. Ps. 32.11.

${ }^{44}$ The translator may have been influenced here by the Epitome of Julian of Eclanum's translation of Theodore of Mopsuestia's commentary, which at this point refers to the animus (Lucas De Coninck [ed.], Theodori Mopsuesteni Expositionis in Psalmos Iuliano Aeclanensi Interprete in Latinum Uersae Quae Supersunt, CCSL 88a [Turnhout, 1977], 115, 11. 20-1; O’Neill [ed.], Prose Translation, 210). 
${ }^{45}$ The glosses from the Vespasian and Regius Psalters has been collected using Pulsiano (ed.), Old English Glossed Psalters.

${ }^{46}$ A search in the Dictionary of Old English (DOE) Corpus produces 176 hits for mod in the Consolation and fifty-three in the Soliloquies; the figures for sawl are thirty-nine and forty-seven respectively, taking into account the spelling variants saul, sawel and sawul; it should be noted that these figures are not an exact guide to the number of occurrences, as each hit can contain multiple instances of the search term (Antonette diPaolo Healey, John Price Wilkin and Xin Xiang, Dictionary of Old English Web Corpus [Toronto, 2009]).

${ }^{47}$ On the scholars gathered by Alfred, see Vita Alfredi cc. 77-9.

${ }^{48}$ On Wisdom's divine nature see B3.2: 'heofencund wisdom' ('divine wisdom'); see also B41.113.

${ }^{49}$ The reference to joy here may have been inspired by the Epitome of Julian of Eclanum's translation of Theodore of Mopsuestia's commentary, which reads '[i]n requiem siue in gaudium' ('into rest or into joy') at this point (De Coninck [ed.], Theodori Mopsuesteni Expositionis in Psalmos, 113, 1. 14; O’Neill [ed.], Prose Translation, 208).

${ }^{50}$ See also B10.55: 'pæet unrote mod' ('that sad mind'). A search in the DOE Corpus shows that there are no cases of unrot sawl or unrot heorte in the Consolation.

${ }^{51}$ For similar examples of the sad mind in the Prose Psalms, see $P S(P)$ 37.9; 41.5 and 13; and 50.9 (cf. Pss. $37.11 ; 41.6$ and 12 ; and 50.10).

${ }^{52}$ DOE, s.v. dysig, definition 1. Definition 2 refers to 'folly' in terms of 'a medical condition treatable by herbal recipes' (Angus Cameron, Ashley Crandell Amos, Antonette diPaolo Healey et al. [eds], Dictionary of Old English: A to $H$ online [Toronto, 2016]).

${ }^{53}$ Pulsiano (ed.), Old English Glossed Psalters, 569-70; definitions from B-T.

${ }^{54}$ See also B39.211-3.

${ }^{55}$ Cf. Soliloquia 1.I.5: 'Sana et aperi oculos meos, quibus nutus tuos videam. Expelle a me insaniam, ut recognoscam te' ('heal and open my eyes, through which I may perceive your wishes, drive out from me delusion, so that I may recognise you'); as in $P s(P) 39.4$, dysig translates insania, contrasting with Old English glosses for Ps. 39.5 in Anglo-Saxon glossed psalters. All quotations and translations from the Soliloquia are taken from St. Augustine of Hippo, Soliloquies, ed. and tr. Watson.

${ }^{56}$ For more on the eagan modes motif in classical antiquity and the Alfredian corpus, see Miranda Wilcox, 'Alfred's Epistemological Metaphors: eagan modes and scip modes', ASE 35 (2006), 179-217. 
${ }^{57} \mathrm{Cf}$. De Consolatione 3m9: 'Da pater augustam menti conscendere sedem, / Da fontem lustrare boni, da luce reperta / In te conspicuos animi defigere visus. / Dissice terrenae nebulas et pondera molis / Atque tuo splendore mica!' (11. 22-6, 'Grant, Father, to my mind to rise to your majestic seat, / Grant me to wander by the source of good, grant light to see, / To fix the clear sight of my mind on you. / Disperse the clouding heaviness of this earthly mass / And flash forth in your brightness.') All quotations and translations from De Consolatione are taken from H. F. Stewart, Edward Kennard Rand and S. J. Tester (eds and trs), Boethius: The Theological Tractates and The Consolation of Philosophy (London; Cambridge, MA, 1973).

${ }^{58}$ Wilcox, 'Alfred's Epistemological Metaphors', 194; on the eagan modes metaphor in the translation of 3m9, see 196.

${ }^{59} \mathrm{Cf}$. 1 Corinthians 13.12: 'videmus nunc per speculum in enigmate / tunc autem facie ad faciem' ('We see now through a glass in a dark manner, but then face to face'). All quotations from the Vulgate are from Weber et al. (eds), Biblia Sacra Iuxta Vulgatam Versionem; all translations from the Vulgate are from Edgar Swift and Angela M. Kinney (eds and trs), The Vulgate Bible: Douay-Rheims Translation, 6 vols, Dumbarton Oaks Medieval Library 1, 4-5, 8, 13, 17 and 21 (Cambridge, MA; London, 2010-2013). Augustine himself was evidently thinking of 1 Corinthians 13.12-3 when, in an earlier section of the Soliloquia, Ratio stipulates that in order to see and thus understand God, the soul requires the trio fides, spes and caritas ('faith', 'hope' and 'charity'), which are the subject of 1 Corinthians 13.13 (Soliloquia 1.VI.12).

${ }^{60}$ On the Soliloquies-author's insistence that both the blessed and the damned will have complete knowledge in the afterlife, and how this compares with the typical patristic attitude, see Malcolm Godden, 'Text and Eschatology in Book III of the Old English Soliloquies', Anglia 121 (2003), 177-209 (189-93 and 199-202). ${ }^{61}$ Wilcox, 'Alfred's Epistemological Metaphors', 202-3 and 213-5.

${ }^{62}$ Cf. Pss. 13.3 and 16.11. O'Neill comments that most interpretations of 'oculos suos statuerunt declinare in terram' ('they have set their eyes bowing down to the earth') in Ps. 16.11 treat 'occulos' as the object, rather than the subject (Prose Translation, 194-5).

${ }^{63}$ The formula 'ægper ge ... mod ... ge ... lichama' occurs on four occasions in the Consolation (B38.190-1; B39.192-3 and 255-6; and in the prose preface [1. 5]), in each of the latter three cases in the context of affliction or illness; there are no parallels in the Latin for any of the occurrences in the body of the Old English text (cf. 4 p4 and 6). This formula, along with the variation 'oððe ... mod ... oððe ... lichama', appears on four occasions in the Soliloquies: 'ægðer ge on mode ge on lichaman' (71.18-9), 'ægðer ge modes ge lichaman' (71.23-4), 'ægðer ge mod ge lichaman' (80.14), 'awðer oððe on mode oððe on lichaman' (80.17); in the first case, at the 
corresponding point in the Latin, Augustine refers to the body, but not the mind, while in the second he refers to the mind, but not the body (1.IX.16); there is no direct parallel for the third (1.XIV.26); and the fourth case corresponds to corpus ('body') in the Latin(1.XIV.26). A similar phrase, 'ne on mode ne on lichaman', follows shortly after the third and fourth occurrences in the Soliloquies (80.19), with no direct parallel in the Latin (1.XIV.26). Versions of the formula, both of the 'ægper ge' and 'oppe' variety, occur on seven occasions in the Prose Psalms and their introductions $(P s(P) 18.8$ and 30.22, and in the introductions to $P s(P) 3,15,27,30$ and 41); in the two cases which do not occur in the Old English introductions, there is no parallel for this phrase in the corresponding Latin verse. A search in the DOE Corpus shows that these formulas only appear elsewhere in the corpus on one other occasion, in the Old English translation of Basil's Admonitio ad Filum Spiritualem. These results are based on a search for 'ægper ge' with 'mod' and 'lichama', and 'oppe' with 'mod' and 'lichama', taking into account spelling variants, including only those examples where the formula begins with 'ægper ge' or 'oppe'.

${ }^{64}$ Augustine of Hippo, Les Commentaires des Psaumes, Ps. 17-25, ed. Martine Dulaey et al., Euvres de Saint Augustin, $8^{\text {th }}$ ser. 57/b (Paris, 2009), 82; Marcus Adriaen (ed.), Magni Aurelii Cassiodori: Expositio Psalmorum, vol. 1, CCSL 97 (Turnhout, 1958), 173.

${ }^{65}$ De Consolatione 1m2, 1m3, 1p6, 1m7, 3m9, 3m10, 3m11 and 5p4; Soliloquia 1.VI.12 and 1.XIII.23. ${ }^{66}$ Cf. Soliloquia 1.XIII.23. On the many occurrences of eagan modes in the Soliloquies, see Wilcox, 'Alfred's Epistemological Metaphors', 202; as Wilcox's Table 1 demonstrates, none of these occurrences are prompted by oculi mentis in the Latin source (213-5).

${ }^{67}$ Wilcox, 'Alfred's Epistemological Metaphors', 182-3; on the oculi mentis metaphor in classical antiquity, patristic writings and the Carolingian world, see 180-1.

${ }^{68}$ Wilcox, 'Alfred's Epistemological Metaphors', 179 and 210.

${ }^{69}$ In fact, Wilcox's Table 1 accounts for only two out of three of the occurrences of eagan modes in the Prose Psalms, omitting the example from $P s(P) 18.8$ (Wilcox, 'Alfred's Epistemological Metaphors', 213).

${ }^{70}$ Lockett, Anglo-Saxon Psychologies, 61-3.

${ }^{71}$ Pulsiano (ed.), Old English Glossed Psalters, 538; miht ('power') is also chosen as a gloss in this verse. The Gallicanum reads virtus ('strength, virtue') instead of fortitudo. As the translator of the Prose Psalms was also familiar with Gallicanum readings, the decision to use craeft here is significant. Peter Clemoes has shown that glossing virtus 'in the moral sense of "virtue", as craft rather than magen, favoured in the Mercian tradition of translation and glossing, is distinctively Alfredian (Peter Clemoes, 'King Alfred's Debt to Vernacular Poetry: 
The Evidence of ellen and craft', in Michael Korhammer, Karl Reichl and Hans Sauer (eds), Words, Texts and Manuscripts: Studies in Anglo-Saxon Culture Presented to Helmut Gneuss on the Occasion of his Sixty-Fifth Birthday [Cambridge, 1992], 213-38 [224-5]). While it is uncertain whether virtus refers to virtue or strength in Ps. 37.11, if the translator has read it as 'virtue', preferring it to the Romanum fortitudo, and glossed it with creeft, this translation decision would, according to Clemoes, be in line with other Alfredian texts.

${ }^{72}$ Clemoes, 'King Alfred's Debt to Vernacular Poetry', 226 and 232; and Nicole Guenther Discenza, 'Power, Skill and Virtue in the Old English Boethius', ASE 26 (1997), 81-108 (95).

${ }^{73}$ Cf. De Consolatione 3m10: 'Non quidquid Tagus aureis harenis / Donat aut Hermus rutilante ripa/ Aut Indus calido propinquus orbi / Candidis miscens uirides lapillus, / Inlustrent aciem magisque caecos / In suas condunt animos tenebras' (11. 7-12, 'Neither what Tagus yields with its golden sands, / Nor Hermus with its ruddy glowing banks, / Nor Indus, next the torrid zone, / Mingling its emeralds and brilliant stones / Would clear men's sight; but in their dark they all / Bury men's even blinder minds'); see also CM21.20-7.

${ }^{74}$ On the grouping together of the senses sight and hearing in the vernacular tradition, primarily in the Laws but also in the Consolation, see Katherine O'Brien O'Keeffe, 'Hands and Eyes, Sight and Touch: Appraising the Senses in Anglo-Saxon England', ASE 45 (2017), 105-40 (111-6 and, especially, 118-9).

${ }^{75}$ See Soliloquies 49.4-6: 'pa answarode me sum ðing, ic nat hwæt, hweðer pe ic sylf pe oðer ping, ne pæt nat, hwæðer hit wæs innan me ðe utan; butan pæs ic soðlicost wene, pat hyt min sceadwisnes were' ('then something answered me, I know now what, whether I myself or some other thing, nor do I know whether it was within me or without; except I truly knew that that it was my reason').

${ }^{76}$ See also Consolation B35.185-6, 187-8 and 197-8; B37.80-1; B39.153-4 and 229-31; and Soliloquies 89.27-8.

${ }^{77}$ On the Consolation-author's engagement with Platonism here, see Godden and Irvine (eds and trs), Old

English Boethius, 2. 401-2. See also Soliloquies 90.17: ‘sec nu on ðe selfum ða bysena and pa tacnu' ('seek now in yourself those examples and those proofs').

${ }^{78}$ Cf. De Consolatione 3m11: 'Quisquis profunda mente vestigat verum / Cupitque nullis ille deviis falli, / In se revolvat intimi lucem visus / Longosque in orbem cogat inflectens motus / Animumque doceat quidquid extra molitur / Suis retrusum possidere thesauris' (1l. 1-6, 'Whoever with deep thought seeks out the truth / And wants not to go wrong down devious ways, / Must on himself turn back the light of his inward vision, / Bending and forcing his far-reaching movements / Into a circle, and must teach his mind, / Whatever she is striving for without, / Removed within her treasury to grasp'); see also CM22.1-16. 
${ }^{79}$ Godden and Irvine note that the ambiguous 'gegæderige to pam anum' 'presumably renders in orbem cogat', which in modern translations is rendered 'as "force into a circle", meaning that the thoughts are turned back into the self'; interpretations similar to the Old English can be found in some glosses to De Consolatione (Godden and Irvine [eds and trs], Old English Boethius, 2. 402).

${ }^{80}$ Greenfield and Calder, A New Critical History of Old English Literature, 55; prose preface to the Pastoral Care, 5.3: 'swæ ðu oftost mæge' ('as often as you can').

${ }^{81}$ Lockett, Anglo-Saxon Psychologies, 355.

${ }^{82}$ Lockett, Anglo-Saxon Psychologies, 355; see Soliloquies 90.19.

${ }^{83}$ In the B-text translation of $3 \mathrm{~m} 11$, on reminiscence, $\bmod$ refers to the faculty that strives to remember (B35.2 and 7), while both mod and sawl are used to refer to the place where the memory is stored (B35.13, 14 and 17); this distinction is preserved in the corresponding metre (CM22.13a, 27a and 38a). Other words for the place where the memory is stored include gemynd (B35.26, 'mind', 'memory'); modsefa (CM22.47a, 'mind', 'spirit', 'soul', 'heart'); runcofa (CM22.59a, 'secret chamber', 'mind', 'breast'); and the phrase modes gemynd (CM22.59a, 'the mind's memory').

${ }^{84}$ Soliloquia 1.I.1; Wilcox, 'Alfred's Epistemological Metaphors’, 181-2. 